\title{
Translingual Discursive Spaces in Language and Arts Lessons
}

\author{
Sarah Degano \\ University of Luxembourg, Luxembourg
}

\begin{abstract}
Flexible multilingual pedagogies such as translanguaging pedagogies are promising stepping stones towards a more equitable access to educational resources for students of different backgrounds. Recent research in Luxembourgish preschool, Year 1 and Year 2 classes, show that teachers have begun to implement such pedagogies by encouraging the deployment of the students' full linguistic repertoires, including their home languages. Little attention has however been paid to the later years of primary school where the achievement gap between students with and without a migration background is particularly high. The present qualitative longitudinal study focusses on students in Years 4 and 5 and examines to what extent they deploy their linguistic repertoires in interaction with their peers. Drawing on observations, recordings and interviews, this paper explores the language use of two Portuguese-speaking $4^{\text {th }}$ graders in Language and Arts lessons. Findings show that the students mobilize their linguistic and cultural resources to different extents and, hereby, open or close translingual discursive spaces for further exchange. The findings should contribute to the understanding of multilingual students' language practices and provide insight into how their linguistic and cultural resources can be capitalized on.
\end{abstract}

\section{Introduction}

Cross-border movements of goods, information and people characterize the reality of the $21^{\text {st }}$ century. Cultures and languages interconnect and blend into one another, leading to increasingly multilingual societies and schools. To engage with this everincreasing multilingualism, students develop linguistic repertoires they can deploy in a flexible and strategic way. However, not all the features of their repertoires are equally valued and perceived as resources in the students' learning; majority languages tend to be supported by language polices whereas languages that deviate from those are not. This unequal support translates into low achievement levels among linguistic minority students [11].

The present paper focusses on Luxembourg. As the country with the highest percentage of immigration in
Europe, Luxembourg presents a particularly diverse linguistic landscape. This diversity is reflected by the education system in which more than $60 \%$ of the students indicate having home languages other than Luxembourgish, with Portuguese being the most used language [12]. Not only are primary schools in Luxembourg linguistically diverse, they also are officially trilingual, providing instruction in Luxembourgish, French and German. With German being the main medium of instruction in primary school, the education system in Luxembourg fails to provide an equitable access to the curriculum for migrant students with a Romance language background. Recent studies have shown that predominantly students of Portuguese and French language background, but also students of Slavic language background underperform compared to Luxembourgish and German speakers [17].

While we have scientific information on the underperformance of certain language groups, we lack information on the language practices of the students. The present paper approaches this issue by exploring the language use of two students with a Portuguese language background in Year 4, where their achievement level is at its lowest [12]. The first part of the paper presents two preliminary analyses that show how the students deploy their linguistic repertoires to communicate with their peers. Drawing on eighteen days of observation, three hours of recorded classroom interactions in German and Arts lessons and one interview with the two students, the second part of the paper discusses the implications of the students' (in)flexible language use. The findings of this paper lay the foundation for the subsequent data analysis. It is hoped that, at a later time, the findings will help understand the language practices in multilingual students and provide information on how their language practices can be capitalized on for educational success.

\section{Flexible multilingual pedagogies}

In response to educational inequity, a growing body of scholars $[5,19]$ promote flexible multilingual pedagogies that aim to, first, draw upon both the minority and the majority languages and, second, 
provide learning opportunities for students with different backgrounds by capitalizing on their linguistic resources. A more flexible multilingual education can, for example, be informed by a diversified offer of educational tracks and different media of instruction or by the responsible implementation of a translanguaging pedagogy. The following section reviews relevant literature on translanguaging by taking an international and a national perspective.

\subsection{Translanguaging and translanguaging pedagogies}

Conceived in 1994, translanguaging is a concept in Education Studies that originally described a bilingual pedagogy in Wales. In the last decade, contributions from the United States and the UK have transformed the original concept and promoted translanguaging as a discursive practice that relates to the languaging of bilingual students. This ever-continuing transformation has led numerous scholars to critique translanguaging for having undergone a profusion of meanings in recent years. In the light of the outlines of the aforementioned education system in Luxembourg, the present article addresses translanguaging as a strategy and as a practice, referring to the alternation between multiple languages.

Predominantly in bilingual school contexts, research has proposed numerous advantages to translanguaging practices. For example, an ethnographic study in a $4^{\text {th }}$ grade Two-Way DualLanguage Program in El Paso, Texas, [3] has shown that translanguaging enabled the students to gain a deeper understanding of the subject matter and a further study in a $2^{\text {nd }}$ grade classroom [16] illustrates that translanguaging allowed the children to create safe discursive spaces to, first, make meaning of the curricular content and, second, construct and perform their identities. The mobilization of the students' linguistic resources translated into the liberation of their funds of knowledge [7]. In a $5^{\text {th }}$ grade English medium mainstream class in Queens, a New York City borough, García and Kleyn [20] have found that teacher translanguaging encouraged the students' participation and in a $2^{\text {nd }}$ grade class for low achieving students in Singapore, Vaish and Subhan [18] have found that it changed the patterns of classroom interaction by ensuring the students' comprehension of the target language and by developing their agentive languaging.

Translanguaging here takes a scaffolding stance [20] with either a pragmatic or an ideological orientation. Whereas the former helps the students acquire the societally dominant language, the latter helps them construct their identities. By doing so, translanguaging includes the students' linguistic resources (the home languages) alongside the social reality (the named school languages), questions the power positions of the school languages and contributes to transforming the educational landscape. When tied to schooling and societal implications, translanguaging practices move beyond the scaffolding stance and become transformative. However, research that defines translanguaging with ties to a political agenda is extremely scarce [13].

To fully explore the potential of translanguaging in the search for social justice, it needs to be implemented as a pedagogical framework that capitalizes on the strategic and responsible deployment of the students' linguistic repertoires. Hence, scholars like Ganuza and Hedman [4] argue that translanguaging should be systematically planned and implemented in learning activities rather than used as an arbitrary 'fall-back' option. Otherwise, unidirectional shifts from one language to the other become recurrent and reiterate inequalities in terms of participation dynamics and power positions. Translanguaging becomes a 'problematic positioning tool' [8] that enables students to leverage their home language in an unequal way. Instead of being a strategy of resistance in the struggle against social inequality, it becomes another dominating force that translates into covert [14] or reductive translanguaging [2], leading students to suppress parts of their cultural and linguistic resources rather than strategically mobilize them to support their learning.

Geared towards a more equitable access to educational resources, a translanguaging pedagogy brings the students' home language practices into the open and connects them to the language practices desired at school. García, Johnson and Seltzer [6] speak about the translanguaging corriente, the current that is always present in a multilingual classroom, albeit it not always is on the surface. That is, even if the class is conducted in the dominant majority language, the students make sense of that language and the curricular content that is taught in that language through their home language and what they already know in that language.

While extensive research has been carried out on translanguaging involving two or three (often official) languages, research on translanguaging involving multiple languages, including the home languages, is relatively rare $[10,15]$. Due to its diverse linguistic landscape, the educational context in Luxembourg is particularly suitable to explore this type of translanguaging.

\subsection{Translanguaging in primary schools in Luxembourg}

In Luxembourg, the instruction of the three official languages not only accounts for $40.5 \%$ of all curricular time, it also is informed by a relatively fixed language teaching and learning regime and, hereby, constitutes an additional challenge for students who 
cannot access the available resources in their linguistic repertoires. Little room is left for linguistic resources other than French, German and Luxembourgish and, accordingly, migrant students' home languages are largely disregarded by the teachers [9]. This disregard significantly reinforces the disjuncture between the language policy in the schools and the language practices of the population of Luxembourg.

Research has shown that, in the primary school, teachers flout the fixity of the language teaching and learning regime by widely drawing on translanguaging practices [19]. However, the translanguaging practices are frequently restricted to shifts from German into Luxembourgish, a Germanic language [18], which equally limits the access to the curriculum for students with a Romance language background. The students' participation dynamics remain hereby unbalanced. For example, spontaneous oral translations from French into Luxembourgish (or German) appear to be a legitimate practice in a lot of classrooms, but translations from Luxembourgish (or German) into French are not.

Conversely, recent studies [10] show that in some Luxembourgish preschool classes as well as in some Year 1 and Year 2 classes, teachers have begun to encourage the deployment of the students' full linguistic repertoires, including their home languages to some extent. Despite the implementation of a flexible multilingual pedagogy in these classes, Kirsch [10] has found that the children's language practices differ significantly in terms of the languages involved. Whereas kindergarteners are deploying all the features of their repertoires while engaging in translanguaging practices, the primary school children in Years 1 and 2 only rarely use their home languages and flexibly move between Luxembourgish and one of the target languages. Yet, thus far, little attention has been paid to the later years of primary school. The teachers might have taken a step towards a more flexible multilingual education, but, simultaneously, their often-exclusive shifts into Luxembourgish further reiterate gatekeeping mechanisms that restrict access to educational and employment opportunities for a large part of the school population.

The present article, however, does not focus on the teachers but on the students and their flexible language use.

\section{Methodology}

The research described in the present paper is a qualitative longitudinal study that investigates, first, the flexible language use of $4^{\text {th }}$ graders with different language and migration backgrounds in a range of school subjects and, second, the development of their language practices across Years 4 and 5. The focus lies on (trans)languaging practices, including the students' home languages. The study uses ethnographic research methods including observations and field notes; video- and audiorecordings, spontaneous discussions, structured conversations and semi-structured interviews. Every fifth week, from January to July 2018 (Year 4) and from September to December 2018 (Year 5), I visited three primary schools in Luxembourg. For three days in a row, I observed and video-recorded the language practices of the students when interacting with their peers and teachers and noted key events, situations in which the students changed from one language to another; used a language other than the languages of instruction; or used their home language(s). Subsequently, some of the video-recordings were shown to and discussed with the students and the teachers in structured conversations to triangulate my interpretations of the data.

The data for the present paper was collected in a Year 4 class in one of the three schools over a period of six months. The class totalled sixteen students of which eight spoke Portuguese as one of their home languages. This paper focusses on two students, Afomito and Raquel, who both are native-Portuguese speakers. Afomito and Raquel use their languages differently at home. While Raquel also speaks Luxembourgish at home to talk to her younger brother, Afomito is an only child and mainly speaks Portuguese at home. In addition, the students have different schooling experiences in the Luxembourgish education system. Raquel spent the previous years in the same primary state school whereas Afomito attended Year 1 in Portugal and only came to Luxembourg in 2014.

The present paper draws on eighteen days of observation, approximately three hours of video- and audio-recordings and one joint interview with Raquel and Afomito. All recordings and conversations were transcribed and analyzed in both an inductive and deductive way. The triangulation of the data sources translated into the following themes: the school subjects, the languages used, the language shifts, the participation patterns, and the purposes of the students' language use.

\section{Findings and Discussion}

This section, first, shows two short excerpts of classroom interactions in Year 4. Analyzed and discussed, both excerpts illustrate how and to what extent two students, Afomito and Raquel, deploy their linguistic repertoires to interact with their peers. Second, the section discusses the implications of the students' language use in relation to knowledge and identity construction processes.

The findings must be interpreted with caution as data analysis is on-going.

All utterances, except for the German ones, are literal translations into English. Whereas the Luxembourgish utterances are coded in plain script, 
the German ones are in italics, the Portuguese ones in bold and the English ones underlined.

\subsection{Two translingual discursive spaces}

The first excerpt stems from a German lesson that was audio-recorded in February 2018. The students were instructed to extend German verbs into adjectives. Afomito (A) is working with Mica (M). Both boys have a similar language background and speak Portuguese and Brazilian Portuguese at home respectively.

\begin{tabular}{|c|c|c|}
\hline 1 & $\mathrm{M}$ & What do we do with teilen [share] \\
\hline 2 & A & $\begin{array}{l}\text { With teilen [share] (pauses) teilig } \\
\text { [shary] }\end{array}$ \\
\hline 3 & $\mathrm{M}$ & No teilen [share] and ehm you know \\
\hline 4 & $\mathrm{~A}$ & Teiler [sharer] \\
\hline 5 & $\mathrm{M}$ & $\begin{array}{l}\text { No (laughs) teilen [share] is you } \\
\text { know you can for example you eat } \\
\text { chocolate right }\end{array}$ \\
\hline 6 & $\mathrm{~A}$ & Yes \\
\hline 7 & $\mathrm{M}$ & $\begin{array}{l}\text { No (pauses) I eat chocolate and I give } \\
\text { you then this is teilen [share] }\end{array}$ \\
\hline 8 & $\mathrm{~A}$ & (remains silent) \\
\hline 9 & $\mathrm{M}$ & $\begin{array}{l}\text { (quickly) You get a bit I get a bit } \\
\text { easy teilen [share] }\end{array}$ \\
\hline 10 & $\mathrm{~A}$ & (laughs) Ok \\
\hline 11 & $\mathrm{M}$ & You know when I do like that \\
\hline 12 & $\mathrm{~A}$ & (laughs) Teilig [shary] \\
\hline 13 & $\mathrm{M}$ & Do like that (imitates eating sounds) \\
\hline 14 & A & $\begin{array}{l}\text { Exactly it is teilig [shary] teilbar } \\
\text { [sharable] }\end{array}$ \\
\hline 15 & $\mathrm{M}$ & $\begin{array}{l}\text { (mutters) Aaah teilen [share] ein Teil } \\
{[\text { a share }]}\end{array}$ \\
\hline 16 & A & (interrupts Mica) Teilig [shary] \\
\hline 17 & $\mathrm{M}$ & Teilen [share] (harshly) shut up \\
\hline 18 & $\mathrm{~A}$ & Teilig [shary] \\
\hline 19 & M & $\begin{array}{l}\text { It is a verb then we have to try with } \\
\text { bar or sam }\end{array}$ \\
\hline 20 & $\mathrm{~A}$ & (exclaims) Exactly \\
\hline 21 & $\mathrm{M}$ & Teilsam [shareful] \\
\hline 22 & $\mathrm{~A}$ & (repeats) Teilbar [sharable] \\
\hline 23 & $\mathrm{M}$ & $\begin{array}{l}\text { (imitates Afomito) Teilbar [sharable] } \\
\text { (pauses) what is this (laughs) }\end{array}$ \\
\hline
\end{tabular}

The second excerpt stems from an Arts lesson that was video-recorded in June 2018, at the end of the school year. The students were given the instruction to invent ice cream flavors and draw the scoops. They work on their drawings when Briana begins to add both the color and the flavor of the ice-cream in English and turns towards Raquel to get help. Raquel (R), Briana (B), Faridah (F), Lena (L) discuss Briana's request. All students are proficient in Portuguese, except for Lena who speaks Spanish and Luxembourgish at home.

\begin{tabular}{|c|c|c|}
\hline 1 & B & $\begin{array}{l}\text { (joins Raquel at her desk and bends } \\
\text { towards her) Which which fruit is } \\
\text { green }\end{array}$ \\
\hline 2 & $\mathrm{R}$ & (stops drawing) Eh fruit is green \\
\hline 3 & $\mathrm{~F}$ & (interrupts Raquel) Apple \\
\hline 4 & $\mathrm{R}$ & (points to her thumb) Apple \\
\hline 5 & $\mathrm{~B}$ & (exclaims)Ah yes \\
\hline 6 & $\mathrm{R}$ & $\begin{array}{l}\text { (points to her index) Pear ehm (points } \\
\text { to her middle finger) banana }\end{array}$ \\
\hline 7 & $\mathrm{~F}$ & Yes \\
\hline 8 & $\mathrm{R}$ & $\begin{array}{l}\text { Yes with when the bananas are not } \\
\text { good (incomprehensible) bananas }\end{array}$ \\
\hline 9 & $\mathrm{~B}$ & (loudly) But I want to write English \\
\hline 10 & $\mathrm{R}$ & Apple \\
\hline 11 & $\begin{array}{c}\text { F\& } \\
\mathrm{L}\end{array}$ & Apple \\
\hline 12 & $\mathrm{R}$ & Yes (pauses) or banana $[\ldots]$ \\
\hline 13 & $\mathrm{~F}$ & Draw an apple like an iPhone \\
\hline 14 & $\mathrm{~L}$ & Is this the same as Portuguese or \\
\hline 15 & $\mathrm{~B}$ & $\begin{array}{l}\text { (writing 'A' but then stops) No it is the } \\
\text { same as Luxembourgish or }\end{array}$ \\
\hline 16 & $\mathrm{R}$ & Aaa (stretches the syllable) pple \\
\hline 17 & $\mathrm{~L}$ & (looks at Briana's writing) Like this \\
\hline 18 & $\mathrm{R}$ & (looks at Briana) Apple yes Apple \\
\hline 19 & $\mathrm{~L}$ & It's like the i-Phone \\
\hline 20 & B & $\begin{array}{l}\text { (looks at Raquel) And the cherry in } \\
\text { English }\end{array}$ \\
\hline
\end{tabular}

Recurrent throughout all the observation periods from January to July 2018, these two examples are representative of the students' language use.

As in the excerpts above, the students regularly open up translingual discursive spaces and flexibly deploy different features of their linguistic repertoires when communicating with their peers, regardless of the school subject and the language of instruction. Although on the margins of the main classroom activity, translanguaging occurs naturally in studentstudent-interactions. These findings are in line with those from other studies that have shown that students are shuttling between languages contributed by others to co-construct meaning $[2,14,15]$. For example, Rosiers [14] has shown that, in spite of a clear policy against multilingualism, translanguaging did occur in student-student-interactions. Rosiers, however, also notes a gradation in the students' use of translanguaging. She argues that, depending on the teacher's attitude towards multilingualism, the students' translanguaging practices increased or decreased with the physical presence of the teacher. As in Rosiers' study, the students in this study were more frequently translanguaging in small group activities than in whole-class activities.

More recently, Rosiers, Van Lancker and Delarue [15] found that translanguaging occurred both in the margins as well as in the centre of the classroom activity. This partially differs from the findings presented here. Although translanguaging also 
occurred on a regular basis in this classroom (like in the classrooms in Brussels and Oudenaarde), it considerably varied in type. In small group activities, the students, except for Afomito, tended to move beyond shifts into one of the official languages and mobilized linguistic resources such as their home language, Portuguese, and English. By contrast, in whole-class activities, the students repeatedly switched from French or German into Luxembourgish. Two possible explanations for the different types of translanguaging may be the teacher's stance towards the students' linguistic and cultural resources and the classroom participants' consistent use of Luxembourgish as the default language. Further information on the 'Luxembourgish-only policy' will be provided further below.

Specifically focusing on Afomito and Raquel, both excerpts also show different scenarios in terms of the languages involved.

Afomito and Raquel use different languages and deploy their linguistic resources to different extents. The first excerpt shows that Afomito communicates in an almost monolingual Luxembourgish mode, irrespective of the languages used by Mica, to manage the conversation and to get the task done. He takes up the discussion by repeating the verb they have to extend (line 2), he signals understanding (lines 6,10) and confirms Mica's utterances (lines 14, 20). In spite of his scarce deviations from Luxembourgish, Afomito intermittently shifts to German (lines 2, 4, $12,14,16,18,22)$ to refer to subject-related terminology. In comparison to Luxembourgish, German plays a subordinate role in Afomito's conversation with Mica and appears to be less salient in his linguistic repertoire. Afomito's 'use' of German is decontextualized and does not fulfil any communicative purpose. Another language he seems to refrain from using is Portuguese. While Mica draws on Portuguese to help him understand (line 9), to accompany his non-verbal communication cues (lines 11,13 ) and to harshly put an end to their language guesses (line 17), Afomito does not use his home language. He does not seem to perceive Portuguese as a resource he can mobilize to, first, mediate his understanding and, second, get the task done. It also is noteworthy that Mica only draws on Portuguese after two unsuccessful explanations in Luxembourgish (lines 5,7). It thus can be suggested that Portuguese may sporadically be used as a bandaid to bridge a temporary lack of understanding. It most certainly is not lived as a language practice. The end of excerpt 1 shows that both Afomito and Mica are struggling to find the right verb extension (lines 20, 21), despite Mica's recourse to Portuguese. Afomito may have made the right guess (lines 14, 21) but that is called into doubt by Mica who, in Portuguese, shows that he does not agree (line 22). The students end up asking the teacher which of the extensions is the right one. Mica's intermittent use of Portuguese is reminiscent of other research findings where translanguaging fulfills a pragmatic scaffolding function to help the students acquire the societally dominant language and ameliorate achievement gaps with a socioculturally informed pedagogy [13]. Vaish and Subhan [18], for example, have shown that the teacher was drawing on the students' home language, Malay, to help them become proficient in the target language, English. Surprisingly, here, it is not the teacher but one of Afomito's peers who engages in 'pedagogical' translanguaging [15] by contextualizing the German word 'teilen' and, hereby, taking over the role of the more knowledgeable other. Occurring at the margins of the classroom, without the teacher being present [14], Mica's translanguaging is likely to be related to his own agentive languaging [18].

The second excerpt focusses on Raquel who, unlike Afomito, communicates in a multilingual mode including Luxembourgish, Portuguese and English. She repeats Briana's (line 2) and Faridah's (line 4) utterances in Portuguese and Luxembourgish respectively, pursues her enumeration in Portuguese (line 6), gives additional explanations in Portuguese (line 8), translates her ideas into English (lines 10, 12) and, finally, evaluates and approves inputs from her peers in Luxembourgish (lines 16, 18). Raquel deploys her linguistic repertoire not only in a flexible but also in a strategic way as she consistently replies in the same language that she was addressed in. Raquel accommodates the linguistic needs of her peers, which shows that she is a highly competent scaffolder. In this situation of joint meaning-making, she makes use of her entire linguistic toolkit, including her home language Portuguese, to engage with her peers. The end of excerpt 2 shows the students further engaging in their discussion. Acknowledging Raquel as the expert, Briana asks her for another word in English (line 20). In this excerpt, Portuguese is an incentive not only to initiate but also to further stimulate and broaden the conversation. The students begin with an enumeration of green fruit (lines 1-8), quickly move on to comparing languages (lines 14-15) and, then, bring in their cultural resources (lines 13, 18). Ultimately, the students discuss the spelling of the English words Raquel has offered. There are similarities between the implications of translanguaging in this study and those described by Woodley [20] and Sayer [16]. For example, in New York City, Woodley [20] has demonstrated that translanguaging is both a mirror of the students' home language practices and a window into new language practices. Like Sasha, one of the students in Woodley's study, Raquel deploys her linguistic resources as a valuable learning and teaching tool. She connects her linguistic and cultural knowledge to the content of the Arts lesson (mirror) and provides new ways of seeing the content for her 
peers (window). Also, like in the $5^{\text {th }}$ grade in Queens, the initial discussion (i.e. about green fruit) evolved into a larger conversation (e.g. of how languages differ and how words are spelled in English). However, unlike the class in Woodley's study, it is not the teacher who provides the framework for the students' translanguaging practices by building on their funds of knowledge [7] and integrating their home languages into learning opportunities, but the student themselves.

It furthermore is remarkable that none of the students brings in either German or French, two languages they been learning for years. This somewhat conflicting result may be due to the fracture between the educational policy and the actual language practices [19] of the current school population. As many students of Portuguese origin do not speak German in their out-of-school lives [19], it is not part of their actual home language practices and integrates their linguistic repertoires in a less salient way. It therefore is not surprising that it does not inform the interactions with their peers. The absence of French is unexpected though and further investigation will be needed to clarify this issue. Interestingly, both languages are not used as a communication tool which is problematic given that German is the language of literacy acquisition and French is taught as a second language.

Both excerpts show that, in spite of their similar language backgrounds, the students deploy their linguistic repertoires to different degrees of flexibility: in the German lesson, Afomito addresses his peers in an almost exclusively monolingual Luxembourgish mode, whereas Raquel communicates in a trilingual PortugueseLuxembourgish-English mode in the Arts lesson. In neither of the lessons, the students draw on French or German.

\subsection{The students' (in)flexible language use and its implications}

The following section discusses the implications of the students' language use in terms of knowledge and identity construction processes.

In excerpt 1 , Afomito engages in language guesses (lines $3,11,13,15,17,21$ ), mechanically trying out all potential extensions. Due to Mica's lack of consolidated knowledge regarding the structure of the German language (lines 20, 22), both engage in 'linguistic ping pong' (lines 14-18, 19-22) and disputes (lines 17, 23). Notwithstanding Mica's explanations in (Brazilian) Portuguese, the conversation leads neither to a deeper understanding of the subject matter nor a quicker and better management of the task. It rather builds on 'back-andforth-utterances' between the participants and ultimately translates into confusion. This excerpt stands in stark contrast to previous studies $[11,3,16]$ which have argued that translanguaging can contribute to develop understanding and knowledge. Esquinca, Araujo and de la Piedra [3] have, for example, linked translanguaging to increased meaning-making processes in Science lessons. There are several possible explanations for Afomito's and Mica's lack thereof in German lessons. A possible explanation might be that the boys' language use at school scarcely includes shifts into their home language. Mica engages in scaffolding mechanisms and temporarily shifts from Luxembourgish into (Brazilian) Portuguese, but Afomito, probably not feeling safe enough to engage in a multilingual conversation and deploy all the features of his linguistic repertoire, continues to address him in Luxembourgish. According to the present data, it can be inferred that translanguaging leads to a deeper understanding if, first, the student is actually translanguaging to communicate and, second, the translanguaging is both expansive [2] and lived as a language practice. Another possible explanation for the lacking link between translanguaging and meaning-making processes might be that the teacher disregards the use of translanguaging as a pedagogical practice. In El Paso [3], the teacher deliberately encouraged the students to draw on their prior knowledge and communicate their thoughts in a bilingual way. She implemented situations of collaborative learning that, based on language mediation, allowed the students to work in their zones of proximal development. In the previous excerpt, it is not the teacher but Mica who tries to mediate Afomito's understanding in a bilingual PortugueseLuxembourgish mode (lines 9, 11, 13 in Portuguese; line 19 in Luxembourgish). Yet, requiring solid skills in and knowledge of German, the task is particularly complicated for students with a Romance language background.

Excerpt 2, on the contrary, displays a situation of co-construction and joint meaning-making where the students build on their peers' previous utterances and remodel them, if necessary. Their conversation does not end abruptly and translates into a situation of meaningful knowledge exchange. In this process, Raquel's multilingual communication mode plays a key role. With a high degree of pragmatic sensitivity, she adapts her language use to the linguistic input of her friends, adopts the role of the more knowledgeable other (lines 1, 14, 15, 17) and, hereby, facilitates not only her own but also her friends' participation in the process of knowledge construction.

The comparison of both excerpts shows that Afomito and Raquel access their linguistic resources to very different extents. While Raquel is actually engaging in expansive translanguaging practices, Afomito completely refrains from doing so. In a joint interview, they explain: 


\begin{tabular}{|l|l|l|}
\hline 1 & Afomito & $\begin{array}{l}\text { In class, I only use } \\
\text { Luxembourgish and } \\
\text { German and French } \\
\text { nothing else }\end{array}$ \\
\hline 2 & Raquel & You also use Portuguese \\
\hline 3 & Afomito & No, I don't \\
\hline 4 & Raquel & $\begin{array}{l}\text { Yes, from time to time. I } \\
\text { use Portuguese from time to } \\
\text { time for my words I don't } \\
\text { know }\end{array}$ \\
\hline 5 & Afomito & $\begin{array}{l}\text { If I do not know the words. } \\
\text { If we speak more } \\
\text { Portuguese, then }\end{array}$ \\
\hline 6 & Raquel & $\begin{array}{l}\text { We almost don't know any } \\
\text { Luxembourgish }\end{array}$ \\
\hline
\end{tabular}

Both students agree on their use of the majority languages in class (line 1) but disagree on their use of Portuguese (lines 2, 3). Especially Afomito's conscious suppression of Portuguese (line 3) suggests the fragility of its status. Both students indicate using their home language as a gap-filler (lines 4, 5) and equate a more frequent use of it with a less developed knowledge of Luxembourgish (lines 5, 6). Elaborating on the students' and the teacher's beliefs would exceed the purpose of the present paper but will be addressed elsewhere.

The two excerpts demonstrate that the students not only access their linguistic resources to different extents, but also their cultural ones. When engaging in the drawing activity, Raquel, Briana, Faridah and Lena mobilize their English skills (lines 10-12) and discuss the spelling of some of the English words by first referring to the iPhone (lines 13, 19), the line of smartphones produced by the American technology company Apple and later to Thunderman Cherry, a character in an American comedy television series. The students relate to their funds of knowledge [7] that are anchored in both the English language and the American media world. Most importantly, however, they actively draw on these funds of knowledge to discuss the spelling of the English words 'apple' and 'cherry'. Despite the fact that further research is needed to better understand the circumstances under which the students open translingual discursive spaces that not only include their linguistic and cultural resources but also sustain translanguaging as a practice to facilitate the access to their funds of knowledge, the comparison of both excerpts reveals the link between translanguaging and the students' funds of knowledge. Whereas Raquel's expansive translanguaging practice allows for the establishment of a connection between the students' prior knowledge, their literacy practices and the curricular content, Afomito's inflexible language use does not.

Afomito's conscious suppression of one language to the benefit of another provides two important pieces of information on the practiced language policy in this classroom [1].
First, Portuguese is perceived as being less 'useful' and less 'legitimate' by Afomito than German or, most importantly, Luxembourgish. He, therefore, does not access some of the features of his linguistic repertoire. In relation to his relatively recent learning experiences in the Luxembourgish education system, Afomito's exclusive use of the majority language(s) constitutes an additional challenge for him which might divest him of a learning opportunity. Raquel, on the other hand, sustains a learning opportunity and does so by translanguaging. Yet, she is translanguaging in an Arts lesson. Although further analyses will be needed to check if she is translanguaging in other school subjects as well (e.g. French, Mathematics, Science), a lack thereof would reiterate the fragile status of Portuguese as the students would only use it as a resource in some of the school subjects rather than in all of them. Recurrently and actively drawn upon in a minor subject (e.g. Arts) but rarely and intermittently drawn upon in a major subject (e.g. German), the students' home languages would not be a part of their language choice patterns [1]. Consequently, expansive translanguaging would neither be a legitimate language practice in the classroom, nor would it provide for a more equitable access to the curriculum. Conversely, it would contribute to reinforce existing inequalities in terms of language statuses and participation dynamics [8].

Second, Luxembourgish is used by Afomito and Raquel as the default language. This resonates with observations from scholars like Horner and Weber [9] who argue that the discourse about the importance of Luxembourgish as the language of integration begins to penetrate the educational context in Luxembourg, in spite of its official trilingualism. The education system in Luxembourg balances towards a 'monolingual identification with Luxembourgish' discourse model that is becoming more important than the traditional model of 'identification with trilingualism' [9]. In contemporary Luxembourg, the students' linguistic integration is perceived to succeed through their use of Luxembourgish.

In that light, the students' language use, flexible or inflexible, constitutes a deviation from the languageof-instruction policy. Both Afomito and Raquel defy the official language policy by using Luxembourgish in a German lesson and Luxembourgish, Portuguese and English in an Arts lesson respectively. The students' (and the teacher's) frequent shifts into Luxembourgish raise questions regarding, first, the role of curricular languages other than Luxembourgish (French and German), second, the existing unequitable access to educational resources for migrant students with a Romance language background and, lastly, the existing performance gap between students with a migration background and students without a migration background. 


\section{Conclusion}

The findings of the present paper have shown that the two Portuguese-speaking $4^{\text {th }}$ graders participate in translingual discursive spaces which include their home language, but they also deploy their linguistic and cultural resources to different degrees of flexibility.

Drawing on relevant literature [5, 6, 11 18, 19, 20], I argue that translanguaging allows for a more equitable access to educational resources for students of different backgrounds. Nonetheless, the findings from the present study have shown that translanguaging has different outcomes in terms of knowledge and identity construction processes. Whereas in one situation, translanguaging is used as short-term scaffolding strategy to bridge a knowledge gap in the acquisition of a majority language, it is used as a practice to sustain joint knowledge construction processes in the other. While the former does not allow for a full deployment of the student's linguistic repertoire and results in confusion and abandonment, the latter liberates the students' linguistic and cultural resources and results in a larger conversation.

Considering that both discursive spaces include the students' home language (albeit not equally used) but do not liberate their funds of knowledge, it is likely that translanguaging, when tapping into the students' funds of knowledge, may facilitate the connection between the students' prior knowledge and the content of the curriculum. Translanguaging would then indeed become transformative [20].

A significant role is played by the teachers who can either ignore, tolerate or capitalize on the students' linguistic and cultural resources. Although the present paper shows the students' agentive languaging while interacting with their peers, translanguaging needs to be moved from the margins of the classroom to its centre and be lived by all the classroom participants as a language practice.

Considering that data analysis is still on-going, no definite conclusion can yet be drawn. However, it is hoped that the findings will contribute to the understanding of students' translanguaging practices in multilingual school contexts. The present research should shed light on, first, how students of different backgrounds deploy their linguistic repertoires to engage in meaning-making processes and, second, how their linguistic and cultural funds of knowledge can be capitalized on for educational success and social well-being.

\section{Acknowledgments}

I am grateful to the students and their teacher who granted me access to their languaging spaces. Without them, I would have been unable to do this research and to further develop my understanding of multilingual practices in the primary school. I would also like to thank Jean-Jacques Weber for his interest in my work and his perceptive comments on earlier versions of this paper. Final thanks go to Claudine Kirsch who, on a daily basis, supports me in my work.

\section{References}

[1] F. Bonacina-Pugh, "Legitimizing multilingual practices in the classroom: the role of the "practiced language policy", International Journal of Bilingual Education and Bilingualism, Routledge Taylor \& Francis Group, DOI: 10.1080/13670050.2017.1372359, 2017, pp. 1-15.

[2] Canagarajah, S., Translingual Practices and Neoliberal Policies: Attitudes and Strategies of African Skilled Workers in Anglophone Workplaces. Springer, Dordrecht, 2017.

[3] A. Esquinca, B. Araujo, and M.T. de la Piedra, "Meaning Making and Translanguaging in a Two-way Dual-language Program on the U.S.-Mexico Border", Bilingual Research Journal 37(2), Routledge, United Kingdom, 2014, pp. 164181.

[4] Ganuza, N. and C. Hedman, "Ideology vs. Practice: Is there a space for translanguaging in mother tongue instruction?" in Paulsrud, B-A., Rosén, J., Straszer, B. \& Wedin, Å., New Perspectives on Translanguaging and Education, Multilingual Matters, Clevedon, 2017, pp. 208226.

[5] García, O. and N. Flores, "Multilingual pedagogies" in Martin-Jones, M., Blackledge, A., \& Creese, A. The Routledge Handbook of Multilingualism, Routledge, New York, 2012, pp. 232-246.

[6] García, O., S. Johnson, and K. Seltzer, The Translanguaging Classroom. Leveraging Student Bilingualism for Learning, Caslon, Philadelphia, 2017.

[7] González, N., L.C. Moll, and C. Amanti, Funds of Knowledge. Theorizing Practices in Households, Communities and Classrooms, Routledge, London, 2005.

[8] L. Hamman, "Translanguaging and positioning in twoway dual language classrooms: a case for criticality", Language and Education 32(1), Routledge Taylor \& Francis Group, DOI: 10.1080/09500782.2017.1384006, 2017, pp. 21-42.

[9] Horner, K. and J.-J. Weber, Introducing Multilingualism: A Social Approach (2 ${ }^{\text {nd }}$ edition), Routledge, New York, 2018.

[10] C. Kirsch, "Young Children Capitalising on Their Entire Language Repertoire for Language Learning at School", Language, Culture and Curriculum, Routledge Taylor \& Francis Group, DOI: 10.1080/07908318.2017.1304954, 2017, pp. 39-55.

[11] G. Lewis, B. Jones, and C. Baker, "Translanguaging: Origins and Development from School to Streets and Beyond", Educational Research and Evaluation 18 (7), Routledge, United Kingdom, 2012, pp. 641-654. 
[12] MENJE, Enseignement fondamental. Education différenciée. Statistiques globales et analyse des résultats scolaires. Année scolaire 2015/2016, MENJE, Luxembourg, 2017.

[13] L. Poza, "Translanguaging: Definitions, Implications, and Further Needs in Burgeoning Inquiry" Berkeley Review of Education 6 (2), Graduate School of Education, Berkeley, 2017, pp.101-128.

[14] Rosiers, K. (2017). "Unravelling Translanguaging: The Potential of Translanguaging as a Scaffold Among Teachers and Pupils in Superdiverse Classrooms in Flemish Education" in Paulsrud, B-A., Rosén, J., Straszer, B. \& Wedin, Å., New Perspectives on Translanguaging and Education, Multilingual Matters, Clevedon, 2017, pp. 148169.

[15] K. Rosiers, I. Van Lancker, and S. Delarue, "Beyond the Traditional Scope of Translanguaging. Comparing Translanguaging Practices in Belgian Multilingual and Monolingual Classroom Contexts", Language \& Communication 61, Elsevier, Netherlands, 2018, pp. 15-28.

[16] P. Sayer, “Translanguaging, TexMex, and Bilingual Pedagogy: Emergent Bilinguals Learning Through the Vernacular", TESOL Quarterly 47(1), TESOL International Association, Michigan, 2013, pp. 63-88.

[17] University of Luxembourg (LUCET), Epreuves Standardisées Bildungsmonitoring für Luxemburg. Nationaler Bericht, University of Luxembourg, Luxembourg, 2014.

[18] V. Vaish, and A. Subhan, "Translanguaging in a Reading Class", International Journal of Multilingualism, 12(3), Routledge, United Kingdom, 2014, pp. 338-357.

[19] Weber, J.-J., Flexible Multilingual Education: Putting Children's Needs First, Bristol, Multilingual Matters, 2014.

[20] Woodley, H.S., "Balancing Windows and Mirrors: Translanguaging in a Linguistically Diverse Classroom" in García, O. \& Kleyn, T., Translanguaging With Multilingual Students: Learning from classroom moments, Routledge, New York, 2017, pp. 83-99. 